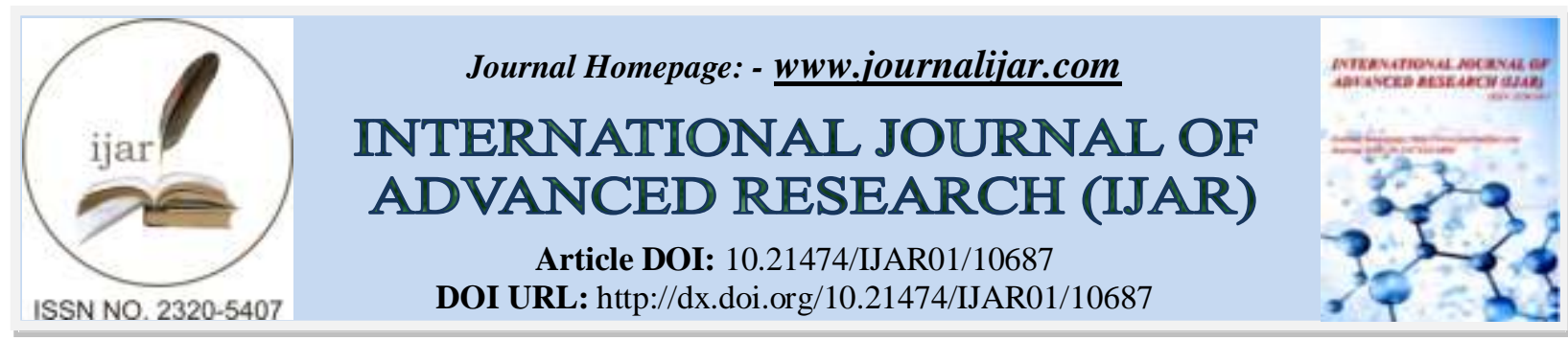

RESEARCH ARTICLE

\title{
BELIEF, RITUAL AND SOCIAL LIFE OF DHIMAL COMMUNITY WITH SPECIAL REFERENCE TO NAXALBARI, NORTH BENGAL
}

\section{Sanjay Das ${ }^{1}$ and Pabitra Paul ${ }^{2}$}

1. Dept. of Sociology (Guest Teacher), Nakshalbari College, Darjeeling, W.B.

2. Research Scholar, Dept .of History N.B.U, Darjeeling, W.B.

\section{Manuscript Info}

...........................

Manuscript History

Received: 17 January 2020

Final Accepted: 20 February 2020

Published: March 2020

Key words:-

Dhimal, Belief, Ritual, Social life,

Purified, Documentary Study

\section{Abstract}

A Little Known Tribal Group Dhimal of North Bengal had Categorized as non-Aryan tribe by various scholars of colonial India such asHodgson,Dalton,Hunter,Risley and 'O'Malley .The present paper is an attempt to explore beliefs, rituals and their(Dhimal) social life which is important aspects of any particular community.Dhimal ritual is performed through different carnivals and festivals. A baby is named without astrological consideration. They prefer usually more son. They burning the married and unmarried death body. The member of the funeral procession are given a feast and the Hara purified.The study is a type of documentary research; data have been collected almost from secondary sources after scanning of existing available literature which are scattered in different form.

Copy Right, IJAR, 2020,. All rights reserved.

\section{Introduction:-}

The name of the tribe under study is "Dhimal" .The word Dhimal does not have special meaning in Dhimal language .other neighbouring communities like tharu and Rajbanshi usually call them Dhimal and Meches call them Maiko.Dhimal People living east of Mai (konki) call themselves as Mallick .

The history was completely silent about the existence of the Dhimals of the Terai before Mr.Hodgson's studied.Even Minhaj-Uddin Siraj in his book 'Tabaqat-e-Nasiri' wrote about the presence of Mech,Koch and Tharu at the time of expedition of Mahhamad Iban Baqtiyar Khalji in 1205 but there also nothing explored about the Dhimals.It was Brain Hodgson who had made first repot in the form of monograph on Dhimals entitled 'Essays the first on the Koch,Bodo,and Dhimal tribes'. Physical feature of the Dhimals are same like the other Mongoloid people with small eyes,half-flattend and wide nose,square face,wide thick lips,black straight and rough hair,yellowish skin and medium height. B.Hodgson said about the Dhimals that,These people ,though dwelling in the forest, apart from the inhabitants of the open country are never guilty of black mailing or of gang-robbery; which among themselves crime of deep dye are almost unknown". Harimohan Sanyal in his book also mentioned about the polite and peaceful nature of Dhimal race.

The Dhimal or Dhemal a little known tribal community of west Bengal had been categorized as non-Aryan tribe before the Independence. North Bengal is a place of various ethno-lingual communities such as Rajbanshi,Bodo,Koch,Mech,Rabha , Dhimal, Limbu, Munda, Santal and so on. But among them Dhimal are very small ethnic group .Now in India Dhimals are concentrated in Maniram, Hatighisa and Buraganja gram panchayet under Nakshalbari block Darjeeling district West Bengal .The Dhimals are scattered in 18 villages constitute 158 
family ,the latest figure of Dhimal population 1005(Terai-Dooars Lok Sanskriti ,April-2018,G.K.Mallick,p-81) ,in between 488 female and 517male. Historian B.H.Hodgson 1847 said " the Dhimal, who seem fast passing away as a Separate race, and whose number do not exceed 15000 souls are at present confined to that portion the saul forest, lying between the Konki and the Dhorla or Torsha, mixed with the Bodo ,but in separate villages and without intermarriages ."

There is a continuous census enumeration on Dhimal population (or sometimes language spoken) up to 1951 except 1941 .The 1872 census identified Dhimal as aboriginal tribe .The 1891 census headed by O'Donnel identified Dhimal as Forest and hill tribes as well as agriculturist by occupation.

\section{Methodology:-}

The data were collected from various sources such as books, journals website and few personal interview has been taken .The study is may be regarded as documentary research .After collection of documents scanning of existing literature there is need some personal interview keeping in mind the specific objectives of the study that is to understand ritual, beliefs and social life of Dhimal community.

\section{Ritual/Belief}

In Hindu mythology the 'Rituals' as such imply some religious and spiritual implications .The sense of refinement and sacredness is essentially related with rituals .Rituals,i.e.,the sansker are those agencies or methods or religious rites which transform a biological man in to a social human being.In other word we can say that the rituals inculcate social characters in human beings and thus make their socialisation possible.

Ritual can be described "as a category of human experience, coming to see it is a more basic than beliefs and integral to the social dimensions of Religion"- (Bell, 1992, 15).The role of ritual is to tie society and culture together.Traditional Indigenous societies have different sorts of rituals, which play an important role in their society as something people share and have in common people continuously practice the rituals as their ancestors used to practice them before. "Ritual give visible expression to the deep cultural norms that order the way people think, feel and evaluate their worlds.They give public expression to the moral order that people believe was defined by the ancestors or instituted by the culture's heroes when they taught people to be civilized and human" (ibid). In Dhimal culture, ritual is performed through different carnivals, feasts and Festivals. The implication of its rituals is situated in its performance, it is at the time of carnivals, feasts and festivals that the rituals become visible. The Performance of the rituals is apparent and clear and its action gives more meanings than words. There are series of rituals associated with all the events of life cycle, for instance birth, marriage and death.

\section{Birth Ceremony:}

In Dhimal no rites are performed before a baby is born. After the child birth, the mother and child are given washing .The child named after the umbilical chord withers away, and the mother also comes out confinement on the same day. A baby is named without astrological consideration.A stranger is named after the nature of his occupation, and babies are named after the day they are born or after some favourite flowers. There are no bindings, any one of the family member can give the babies name. Though they do not specially celebrate the birthday ceremonies of a son and daughter. The Dhimal usually give more son preference.

\section{Marriage:}

The one of the happiest ceremony of Dhimal is marriage ceremony. They use to make the house beautiful with bamboo and grass and hang up the pig legs (locally call it fila) which is found today. It is a full of Entertainment on which dance,quiz and songs competition between both parties beside homemade wine and meat .In Dhimal society there is a 10 (Ten) social Sanctions which is mandatory for every couple to have to obey unless the couple does not to be allowed to live in their society .

\section{Death:}

The death ceremony of Dhimal is too much complex. Although as a Primitive community as usually their religion is Animistic type so all the events of Dhimals surrounding death is magical. The rituals of burying and burning the married and unmarried dead are largely some minor differences. The dead body of an unmarried boy or girl plants of banana or flowers are planted on the grave .This, however is not the customs in the case of married ones .while burying the dead, fowls are sacrificed along with the offer of rice and drink .Purification rituals is performed at one's convenience. This take places on the fourth day of the death, in most cases .Until the purification rite takes place , 
every member of the family and related kins should all observe the mourning. On the day of purification the member of the funeral procession are given a feast and the Hara

purified.

In the Dhimal society,in every traditional village there is a village headman who is appointed for the protection and development of the village.In Dhimal society the Majhi is respected as the village chief .The main duty of Majhi is to solve the social problems that occurs in the village. He become a Majhi, he play his role to makes a social life smooth and steady. The Majhi should be a honourable ,respected and rich.If the Majhi dies ,his oldest son will be chosen as the next Majhi of this village. And another is call Dhami represent a religious leader or a priest.The duty of the priest is to protect the village from external and internal supernatural threts such as evil spirits, diseases and starvation . The Ojha is also call witch doctor who drive out the evil spirit through his power. (Regmi,2007;103)

Dhimals have kept their religion traditional and faith until now.They does not worship any idol as like Hindu worshiped. Nature is considered omnipotent and then worshipped on several occasions, death, sickness, poverty, children wealth,

marriage and all other phenomena are ascribed to the temperance of the God and believed thereafter. According to popular beliefs all the Dhimal deities can be divided into two groups - Family God and Village God .Three important festivals of the Dhimals were Harijata held in December -January at the time of ripening of cotton crop,Gavipuja held in July-August at the time of rice comes into ear and last one Pachima-paka celebrated in October. The former two related to agriculture mainly held on bank of river and last one observed inside the house. But with the course of time many of the festivals gradually lost of her propensities in society.Dhimal society organized Gram-Puja(village God) in every year, it is a collective celebration for the villagers welfare .

\section{Summary:}

The social system of Dhimal is distinct from other indigenous communities. They have established a different social structure and organization that is helpful to maintain and promote their own traditional norms and values. But an organization call 'Dhimal Astitya Raksha Samity' has been formed. The prime face of this organization is Garjan kumar Mallick. He has shared his personal views that, today's Dhimal proceeding with a very hardiest time .Many cultural treat has been changed because of unavoidable dominant forces. Today ,Dhimal society feels the crisis of their rich culture and tradition Which are need to be serious study and government intervention.

\section{References:-}

1. Risley Herbert Hope (1891).The Tribes and Castes of Bengal (vol-1).Reprint 1998.Calcutta;Firma KLM Pvt.Ltd.

2. Regmi,Rishikeshab R.(1985).Cultural patterns and economic change: anthropological study of Dhimals of Nepal.Kathmandu,Nepal :Delhi: sandeep Regmi; Motilal Banarasi Dass.

3. Rai ,Janak.(2013).Activism as a moral practice : history,place making and indigenious movements in Nepal .Phd thesis,University of Michigan.

4. Biswas, Subir (2008).The Dhimals- A Little Known Tribal Group of sub-Himalayan West Bengal:Historical Perspectives,stud Tribes Tribals,6(2):117-121.

5. Roy,Ranjit (1999).The Dhimals-A Lillte Known Community of sub-Himalaya Bengal (An Ethnograpic Overview).M.Phil.Dissertation ,siliguri:Centre for Himalaya studies,North Bengal University.

6. B,Krisna\&A, Chandan.(june,2015).A Historical Analysis on the Social Life of the Dhimals of North Bengal.Vol-4,Issue-6,p-147-148. International Journal of Innovative Research and Development.

7. A,J, Dash. Bengal Dristic Gazetteers : Darjeeling,Reprint 2011,N.L publisher,West Bengal.

8. Bandyopadhyay,Sekhar(2004).Dhimal (in Bengali).Kolkata, Centre for folklore and Tribal Culture, Goverment of West Bengal.

9. Personal Interview: Sri, Garjan kumar Mallick, Age (54aprox) president of "Dhimal Astitya Raksha Samity".Date of interview -23/11/19 and 29/11/19.place- Nakshalbari.

10. Mallick,G.k.(April,2018)Terai-Dooars Lok Sanskriti( In Bengali ),p-81, bagnio sahitya sangsad ,Kolkata.

11. Bell,Catherine,(1992;15),Ritual Theory, Ritual Practice, Oxford university press. New York. 